\title{
Wpływ rodzaju układu rozpylającego i sposobu natryskiwania na koszty wykonania powłok natryskiwanych łukowo
}

\author{
Cost of arc sprayed coatings depending \\ on the type of atomizing chamber \\ and some of spraying parameters
}

\section{Streszczenie}

W artykule przedstawiono wyniki badań wpływu odległości natryskiwania, kąta natryskiwania, napięcia łuku, ciśnienia powietrza rozpylającego, rodzaju materiału powłokowego oraz rodzaju układu rozpylającego w pistoletach łukowych na wielkość strat materiału powłokowego, a więc koszty materiałowe. Badania wykonane zgodnie z normą PN-EN ISO 17836 wykazały, że przy nadmiernym zwiększeniu odległości natryskiwania koszty materiałowe mogą wzrosnąć nawet dwukrotnie. Stwierdzono, że dzięki zastosowaniu stopu $\mathrm{Zn}-\mathrm{Al}$ zamiast $\mathrm{Zn}$ można koszty materiałowe zmniejszyć o ok. $10 \div 12 \%$.

\section{Wstęp}

Podstawowym wymaganiem stawianym dobrej ochronie przed korozją jest spełnienie określonych zadań przy możliwie najniższych kosztach. Do zadań tych zalicza się:

- wystarczającą trwałość wybranego systemu ochronnego w warunkach eksploatacji,

- dopasowanie systemu ochronnego do żądanego czasu użytkowania przy możliwie małych kosztach konserwacji lub renowacji,

- wykonanie systemu zgodnie z wymaganiami jakościowymi przy możliwie najmniejszym zagrożeniu dla środowiska.

Prof. dr inż. Witold Milewski, mgr inż. Anna Olbrycht, inż. Szymon Pawlik - Instytut Mechaniki Precyzyjnej, Warszawa.

\section{Abstract}

The test results of the influence of spraying distance, spraying angle, arc voltage, atomizing air pressure, metal type and atomizing chamber type in arc spraying gun on materials loss and coating costs are discussed. Tests carried out according to PN-EN ISO 17836 showed that too big spraying distance could increase material loss even twice. Replacing of $\mathrm{Zn}$ by $\mathrm{Zn}-\mathrm{Al}$ alloy may decrease the costs of about $10 \div 12 \%$.
Wieloletnie doświadczenie i wyniki prac badawczych jednoznacznie potwierdzają, że najbardziej trwałą ochronę przed korozją zapewniają powłoki metalowo-malarskie. W budownictwie mostowym i drogowym przewidywanym do wieloletniej eksploatacji, jedną z najbardziej istotnych spraw jest zapewnienie długoletniej ochrony konstrukcji. Dlatego w ostatnim 15-leciu obserwuje się intensywny rozwój badań mających na celu wykorzystanie niewątpliwej zalety powłoki metalowej, np. cynkowej, w postaci wysokiej odporności korozyjnej i ochraniających właściwości elektrochemicznych w połączeniu z coraz lepszymi właściwościami ochronnymi powłok malarskich, co w połączeniu pozwala na opracowanie systemu ochronnego bardziej ekonomicznego, wykorzystującego synergizm działania obu zastosowanych powłok.

Przy obecnym stanie techniki nakładania powłok metalowych na konstrukcje stalowe, z różnych metod 
Tablica I. Trwałość powłok cynkowych zanurzeniowych (ogniowych) w zależności od grubości i kategorii agresywności środowiska (wg PN-EN ISO 14713-1) [2]

Table I. Durability of hot-dip galvanizing coating in dependence from thickness and category of corrosivity (EN ISO 14713-1) [2]

\begin{tabular}{|c|c|c|c|c|c|c|c|c|c|c|}
\hline \multirow[t]{2}{*}{ Rodzaj powłoki } & \multirow[t]{2}{*}{ Zgodność z normą } & \multirow{2}{*}{$\begin{array}{l}\text { Grubość } \\
\text { minimalna, } \mathrm{mm}\end{array}$} & \multicolumn{8}{|c|}{$\begin{array}{l}\text { Kategoria agresywności środowiska wg ISO } 9223 \\
\text { Trwałość min/max w latach. Oznaczenie trwałości }\end{array}$} \\
\hline & & & \multicolumn{2}{|c|}{ C3 } & \multicolumn{2}{|c|}{$\mathrm{C} 4$} & \multicolumn{2}{|c|}{ C5 } & \multicolumn{2}{|c|}{$C X$} \\
\hline \multirow{3}{*}{ Zanurzeniowa } & \multirow{3}{*}{ PN-EN ISO 1461} & 85 & $40 />100$ & $\mathrm{VH}$ & $20 / 40$ & $\mathrm{VH}$ & $10 / 20$ & $\mathrm{H}$ & $3 / 10$ & $M$ \\
\hline & & 140 & $67 />100$ & $\mathrm{VH}$ & $33 / 67$ & $\mathrm{VH}$ & $17 / 33$ & $\mathrm{VH}$ & $6 / 17$ & $\mathrm{H}$ \\
\hline & & 200 & $95 />100$ & $\mathrm{VH}$ & $48 / 95$ & $\mathrm{VH}$ & $24 / 48$ & $\mathrm{VH}$ & $8 / 24$ & $\mathrm{H}$ \\
\hline
\end{tabular}

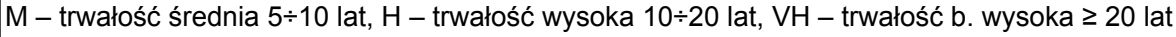

nakładania takich powłok można praktycznie wykorzystać tylko dwie:

- metodę zanurzeniową (ogniową), przy czym można nakładać praktycznie tylko cynk, lub cynk z niewielkim dodatkiem innych pierwiastków, takich jak $\mathrm{Al}, \mathrm{Ni}, \mathrm{Bi}, \mathrm{Sn}$ i in.,

- metodę natryskiwania cieplnego umożliwiającą nakładanie powłok na dowolnie duże elementy z różnych materiałów, przy czym do ochrony przed korozją wykorzystuje się przeważnie Zn, Al i ich stopy.

Powłoki zanurzeniowe (ogniowe) pochłaniają 70\% cynku zużywanego na wszystkie powłoki ochronne [1].

Grubość powłoki cynkowej jest podstawowym, ale nie jedynym parametrem determinującym czas ochrony antykorozyjnej, jednak powłoki zbyt grube mogą wykazywać gorszą przyczepność.

Powłoki cynkowe zanurzeniowe (ogniowe) zapewniają najdłuższą odporność na korozję atmosferyczną (tabl. I).

Ze względu na wielkość i masę konstrukcji mostowych początek wykorzystania ogniowych powłok cynkowych nastąpił dopiero w latach 70 . ub.w. I tak w 1974 r. w Wielkiej Brytanii zastosowano cynkowanie ogniowe do ochrony przed korozją mostu w Cleveland. Kontrole przeprowadzone w latach 1979, 1989 i 1997 potwierdziły, że po 25 latach eksploatacji ubyło praktycznie $35 \mu \mathrm{m}$ powłoki. Z powłoki o wyjściowej grubości $150 \mu \mathrm{m}$ w najcieńszym miejscu pozostało $115 \mu \mathrm{m}$. Oznacza to, że przez co najmniej następne 25 lat powłoka nie będzie wymagała konserwacji.

W Japonii pierwsze podpory mostowe o długości 13 m ocynkowano ogniowo w 1963 r. Od roku 1970 nastąpiło intensywne wykorzystanie tej metody w budownictwie mostowym. Stwierdzono, że roczne ubytki powłoki Zn nie przekroczyły $1,87 \mu \mathrm{m}$ na rok, co oznacza 41 -letnią trwałość powłoki o grubości $85 \mu \mathrm{m}$ [3].

W Kanadzie podczas remontu i poszerzania mostu w Toronto w 1969 r. zastosowano trzy technologie:

- trzywarstwową powłokę malarską z gruntem wysokocynkowym,

- cynkowanie ogniowe nowych części, przy czym części oryginalne pokrywano powłoką malarską,

- cynkowanie ogniowe nowych części i natryskiwanie cieplne części oryginalnych - starych.

Po 20 latach eksploatacji w 1989 r. najbardziej trwałe okazało się rozwiązanie trzecie, które nie wymagało żadnych uzupełnień. Powłoka malarska została uzupełniona w $1981 \mathrm{r}$.
Drugą metodą, uzupełniającą cynkowanie ogniowe, jest natryskiwanie cieplne umożliwiające nałożenie powłoki na konstrukcje o dowolnych wymiarach.

W Europie pierwsze wielkie konstrukcje stalowe zabezpieczano natryskowo cynkiem już w latach XX ub.w., a w USA niespełna dekadę później. Nałożone wówczas powłoki do dziś nie wymagają praktycznie żadnych zabiegów naprawczych, nie mówiąc o samych konstrukcjach, które pomimo ponad $80 \div 90$ lat użytkowania pozostają w stanie nienaruszonym. Metodę tę przyjęto jako podstawowy sposób ochrony przed korozją. Tak np. w Nowej Zelandii metalizuje się rocznie ponad $100000 \mathrm{~m}^{2}$ powierzchni (przy 3,8 mln mieszkańców). Od połowy lat 90., tj. od wprowadzenia w USA zaleceń dotyczących długotrwałego zabezpieczenia konstrukcji mostowych przed korozją, w Stanach Zjednoczonych i Kanadzie metalizuje się 10-krotnie więcej mostów niż przed opublikowaniem tego dokumentu [4]. Stanowe DOT (Departamenty Transportu), mając na uwadze korzyści finansowe wynikające ze stosowania metalizacji, wprowadzają ją do obowiązujących systemów ochronnych, umieszczając na pierwszym miejscu [5]. Norweska Statens Vegvesen, odpowiednik polskiej Generalnej Dyrekcji Dróg Krajowych i Autostrad, jako główną metodę ochrony stalowych mostów przed korozją wymienia natryskiwanie cieplne. W Norwegii metalizuje się niemal wszystkie obiekty mostowe, a w Wielkiej Brytanii ok. 80\% [6]. Metalizacja jest powszechnie stosowana na platformach wiertniczych, turbinach wiatrowych i innych obiektach, których trwałość jest zakładana na więcej niż 50 lat [7].

W Polsce powojenne początki nie były łatwe. Pierwszy most (stojący do dziś bez żadnej konserwacji) pometalizowano w 1957 r., po czym nastąpiła długa przerwa. Metalizowano tylko nieliczne obiekty, przeważnie budowle hydrotechniczne. Natomiast dość intensywnie rozwijało się wykorzystanie antykorozyjnych powłok natryskiwanych cieplnie w przemyśle chemicznym (fabryki kwasu siarkowego), spożywczym (branża cukrownicza) i papierniczym. Projektanci oraz główni wytwórcy konstrukcji stalowych niechętnie stosowali tę technologię $\mathrm{w}$ budownictwie mostowym. Inna rzecz, że jakość sprzętu do metalizacji, a przede wszystkim jego mała wydajność, były przyczynami wysokich kosztów procesu.

Po 1989 r. nastąpiły istotne zmiany. Możliwy stał się dostęp do wysokowydajnego i tańszego 
Tablica II. Porównanie kosztów wykonania i eksploatacji różnych systemów ochrony przed korozją

Table II. Comparison of final costs and functioning of various corrosion protection systems

\begin{tabular}{|l|c|c|c|}
\hline \multicolumn{1}{|c|}{ Rodzaj systemu } & $\begin{array}{c}\text { Koszt } \\
\text { wykonania } \\
\text { zł/m² }\end{array}$ & $\begin{array}{c}\text { Roczny } \\
\text { koszt } \\
\text { eksploatacji } \\
\text { zł/m² }\end{array}$ & Źródło \\
\hline Powłoka cynkowana ogniowo & 30 & 0,99 & 8 \\
\hline $\begin{array}{l}\text { Powłoka malarska grunt } \\
\text { wysokocynkowy + EP }\end{array}$ & 50 & 4,95 & 8 \\
\hline Powłoka metalizacyjno-malarska & 129,3 & 4,71 & 9 \\
\hline Powłoka malarska trzywarstwowa & 84 & 9,42 & 9 \\
\hline Powłoka malarska dwuwarstwowa & 75 & 11,0 & 9 \\
\hline $\begin{array}{l}\text { Grunt wysokocynkowy } \\
+ \text { EP + PUR }\end{array}$ & 90 & 10,6 & 10 \\
\hline $\begin{array}{l}\text { Powłoka metalizacyjno-malarska } \\
150 \mu \text { m Zn + EP + PUR }\end{array}$ & 150 & 6,6 & 10 \\
\hline
\end{tabular}

w użytkowaniu sprzętu do metalizacji. Powstały pierwsze firmy metalizacyjne wyposażone w sprzęt klasy światowej. Krajowy producent drutu cynkowego pokonał problemy natury jakościowej. Powstawały projekty mostów dostosowanych do ochrony za pomocą metalizacji (most w Broku), rozpoczęto na szerszą skalę metalizowanie wiaduktów kolejowych. Po roku 1993 pometalizowano w Polsce kilkadziesiąt mostów, stalowych kominów fabrycznych, wiaduktów drogowych i kolejowych. Wykonane na tych obiektach powłoki metalizacyjno-malarskie, pomimo że w niektórych przypadkach minęło już 20 lat eksploatacji, nie wymagały dotychczas najmniejszych uzupełnień. Wykazały bardzo wysoką trwałość, przy czym (jak wynika z danych literaturowych), powłoki te charakteryzują się niskimi kosztami eksploatacji (tabl. II).

\section{Cel i zakres badań}

Jedną z wad procesu natryskiwania cieplnego są straty materiału powłokowego użytego do wytworzenia powłoki.

Część cząstek natryskiwanych nie osiada na materiale podłoża. Cząstki znajdujące się na obrzeżach strumienia natryskowego są gwałtownie chłodzone, mają mniejszą prędkość i w wyniku tego za małą energię, aby ulec odkształceniu i zakleszczeniu w materiale podłoża. W materiałach powłokowych o niskiej temperaturze topnienia część cząstek ulega odparowaniu. Wielkość tego typu strat, spowodowanych samym procesem natryskiwania, zależy z jednej strony od rodzaju materiału powłokowego (m.in. od jego temperatury topnienia i parowania), z drugiej zaś od metody natryskiwania, rozwiązania konstrukcyjnego pistoletu do natryskiwania i parametrów (w tym m.in. od odległości natryskiwania).
Do nakładania powłok na konstrukcje wielkogabarytowe o dużych powierzchniach używa się wyłącznie drutowych pistoletów łukowych, które umożliwiają nakładanie powłok ochronnych przy najmniejszych nakładach energetycznych. W pistoletach stosowane są najczęściej dwa systemy rozpylania topionego materiału: system otwarty i system zamknięty, powodujący powstawanie cząstek o mniejszych rozmiarach, w wyniku czego natryskiwaną powłokę cechuje mniejsza porowatość.

Należy przypuszczać, że ze względu na różny sposób rozpylania i różną wielkość cząstek natryskiwanych, w obu procesach niejednakowa ilość materiału powłokowego będzie osadzać się na materiale podłoża i tworzyć efektywnie powłokę natryskiwaną. Wielkość strat powstających wskutek stosowania różnego materiału powłokowego i różnych pistoletów może mieć istotny wpływ na koszty wytwarzania powłoki.

Pomimo tego, że w przypadku długoletniego użytkowania konstrukcji zabezpieczonych powłoką metalowo-malarską, koszty eksploatacji są najniższe, jednak w wielu przypadkach o wyborze metody decyduje określony w przetargu początkowy koszt wykonania obiektu. Istotne jest więc ustalenie, w jaki sposób zastosowane parametry natryskiwania mogą wpływać na koszt wytworzenia metalowej powłoki.

Ważne jest więc stwierdzenie, w jaki sposób zastosowany system rozpylania i użyte parametry natryskiwania wpływają na wielkość strat materiału powłokowego podczas natryskiwania, a więc na ilość materiału potrzebnego do nałożenia powłoki o założonej grubości, a przez to na czas natryskiwania powłoki i koszt materiału powłokowego.

Wielkość strat powstających podczas procesu natryskiwania oceniono wg normy PN-EN ISO 17836:2006 Natryskiwanie cieplne. Określenie współczynnika osadzania powłoki natryskanej cieplnie. Natryskiwanie wykonano przy użyciu pistoletu łukowego LD-U2 firmy OSU-Maschinenbau. Pistolety tej firmy są w Polsce najczęściej stosowanymi urządzeniami do nakładania metalowych powłok ochronnych. Zgodnie z normą próbki z blachy stalowej o wymiarach $300 \times 300 \times 2 \mathrm{~mm}$ poddano obróbce strumieniowo-ściernej elektrokorundem o ziarnistości 24 i po uzyskaniu czystości powierzchni Sa3 odpylano strumieniem sprężonego powietrza i ważono z dokładnością $0,1 \mathrm{~g}$. Następnie próbki mocowano w odpowiednim uchwycie i natryskiwano przy następujących parametrach:

I - przy badaniu wpływu odległości natryskiwania:

- natężenie prądu I $=200 \mathrm{~A}$,

- ciśnienie powietrza rozpylającego $p=0,45 \mathrm{MPa}$,

- napięcie U $=19 \mathrm{~V}$,

- kąt natryskiwania $\alpha=90^{\circ}$,

- odległość natryskiwania $I=150,200,300,400$, $600 \mathrm{~mm}$;

II - przy badaniu wpływu kąta natryskiwania:

- natężenie prądu I $=200 \mathrm{~A}$,

- ciśnienie powietrza rozpylającego $p=0,45 \mathrm{MPa}$,

- napięcie U $=19 \mathrm{~V}$,

- odległość natryskiwania I $=150 \mathrm{~mm}$,

- kąt natryskiwania $\alpha=90,60,45,30^{\circ}$; 
III - przy badaniu wpływu napięcia łuku:

- natężenie prądu I $=200 \mathrm{~A}$,

- ciśnienie powietrza rozpylającego $p=0,45 \mathrm{MPa}$,

- odległość natryskiwania I $=150 \mathrm{~mm}$,

- kąt natryskiwania $\alpha=90^{\circ}$,

- napięcie $U=19,24,31 \mathrm{~V}$;

IV - przy badaniu wpływu ciśnienia powietrza rozpylającego:

- natężenie prądu I $=200 \mathrm{~A}$,

- napięcie U = $19 \mathrm{~V}$,

- odległość natryskiwania I $=150 \mathrm{~mm}$,

- kąt natryskiwania $\alpha=90^{\circ}$,

- ciśnienie powietrza rozpylającego $p=0,45 ; 0,3$; $0,2 \mathrm{MPa}$.

Natryskiwanie wykonano przy użyciu manipulatora zapewniającego stałą odległość natryskiwania, jednakowy sterowany komputerowo ruch pistoletu i jednakowy czas natryskiwania (rys. 1). Natryskiwanie próbki

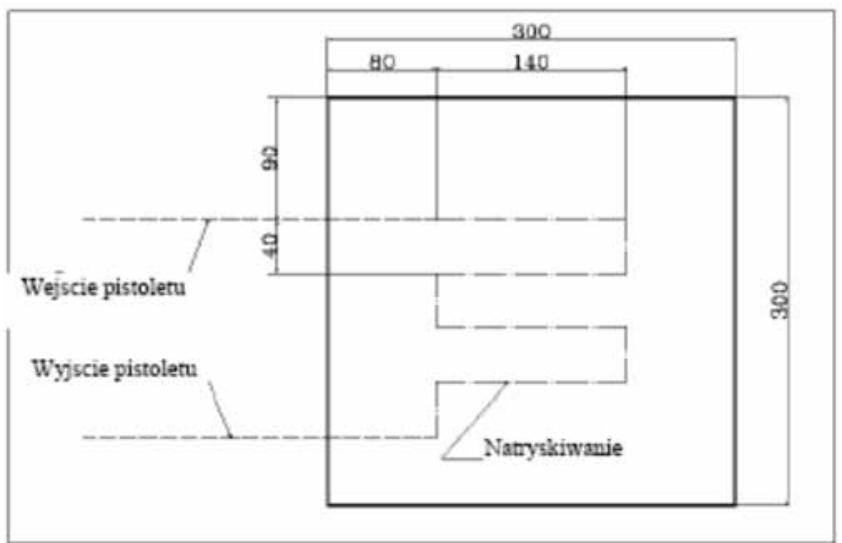

Rys. 1. Schemat ruchów pistoletu względem próbki do wyznaczania współczynnika osadzania powłoki

Fig. 1. Scheme of the gun movement on the sample for deposition efficiency

Tablica III. Zestawienie wyników pomiarów uzyskanych podczas natryskiwania drutem $\mathrm{Zn} ø 2,5 \mathrm{~mm}$ oraz Zn-Al 85/15 ø 2,5 mm przy natężeniu $200 \mathrm{~A}$, napięciu $19 \mathrm{~V}$ i ciśnieniu rozpylania 0,45 $\mathrm{MPa}$

Table III. Measurement results during thermal arc spraying $\mathrm{Zn} ø 2,5$ $\mathrm{mm}$ and $\mathrm{Zn}-\mathrm{Al} 85 / 15 \varnothing 2,5 \mathrm{~mm}$, current $200 \mathrm{~A}$, voltage $19 \mathrm{~V}$, atomizing air pressure $0,45 \mathrm{MPa}$

\begin{tabular}{|c|c|c|c|c|c|c|c|c|}
\hline \multirow{2}{*}{$\mathrm{L}$} & \multicolumn{4}{|c|}{ Zn } & \multicolumn{4}{c|}{ Zn-Al 85/15 } \\
\cline { 2 - 9 } & \multicolumn{2}{|c|}{$\eta_{\mathrm{D}}, \%$} & \multicolumn{2}{c|}{$\mathrm{M}, \mathrm{kg}$} & \multicolumn{2}{c|}{$\eta_{\mathrm{D}}, \%$} & \multicolumn{2}{c|}{$\mathrm{M}, \mathrm{kg}$} \\
\cline { 2 - 9 } & $\mathrm{o}$ & $\mathrm{z}$ & $\mathrm{o}$ & $\mathrm{z}$ & $\mathrm{o}$ & $\mathrm{z}$ & $\mathrm{o}$ & $\mathrm{z}$ \\
\hline 150 & 56,87 & 62,07 & 1,13 & 1,11 & 67,28 & 73,31 & 0,74 & 0,73 \\
\hline 200 & 54,67 & 53,21 & 1,17 & 1,30 & 65,66 & 69,11 & 0,76 & 0,77 \\
\hline 300 & 50,54 & 31,66 & 1,27 & 2,18 & 63,21 & 52,12 & 0,79 & 1,02 \\
\hline 400 & 44,22 & 19,27 & 1,46 & 3,58 & 56,91 & 35,61 & 0,88 & 1,49 \\
\hline 600 & 30,82 & 6,74 & 2,09 & 10,26 & 39,21 & 14,60 & 1,28 & 3,64 \\
\hline
\end{tabular}

Oznaczenia:

L - odległość natryskiwania,

$\eta_{\mathrm{D}}$ - współczynnik osadzania,

$\mathrm{M}$ - ilość materiału powłokowego koniecznego do natryskiwania

$1 \mathrm{~m}^{2}$ powłoki o grubości $100 \mathrm{~mm}$,

o - natryskiwanie $z$ otwartym układem rozpylania,

z - natryskiwanie z zamkniętym układem rozpylania. trwało 30 s, po czym próbki demontowano i ważono. Różnica masy próbki oraz masy użytego drutu umożliwiła obliczenie współczynnika osadzania.

Gęstość natryskiwanych powłok określono przez pomiar objętości i masę natryskiwanej powłoki. W tym celu powierzchnię próbki stalowej o wymiarach $150 \times 100 \times 2 \mathrm{~mm}$ przygotowano za pomoca obróbki strumieniowo-ściernej, ważono z dokładnością do 0,01 g i natryskiwano na grubość ok. 0,8 mm. Następnie próbkę ponownie ważono i z różnicy określano jej masę. Po zmierzeniu grubości powłoki przy użyciu przyrządu Elcometer 355 określano objętość powłoki i obliczano jej gęstość. Ze względu na małą dokładność tego rodzaju pomiaru, gęstość obliczono jedynie dla wartości granicznych, w celu poznania tendencji zmian zachodzących w strukturze powłoki.

Ruchy pistoletu były sterowane za pomocą manipulatora GTV 2-AH1500/500.

Parametry przesuwu pistoletu:

- prędkość przesuwu w osi X - $1550 \mathrm{~mm} / \mathrm{min}$

- prędkość przesuwu w osi Y - $1550 \mathrm{~mm} / \mathrm{min}$

- wartość kroku $\quad-40 \mathrm{~mm}$

- liczba kroków - 2

\section{Wyniki badań}

\section{Wpływ odległości natryskiwania}

Wyniki pomiarów przedstawiono w tablicy III. Na ich podstawie stwierdzono, że:

- Sprawność procesu natryskiwania, czyli ilość materiału tworząca efektywnie powłokę ochronną, w istotny sposób zależy od odległości natryskiwania.

- Wielkość strat materiału powłokowego przy natryskiwaniu łukowym zależy również m.in. od zastosowanego systemu rozpylania i przy prawidłowej odległości natryskiwania $150 \div 200 \mathrm{~mm}$ straty te są najmniejsze, a na podłożu osiada ok. $60 \% \mathrm{Zn}$ i 70\% Zn-Al 85/15. Jednak ze wzrostem odległości natryskiwania ilość osadzanego materiału gwałtownie maleje i przy odległości $600 \mathrm{~mm}$ wynosi odpowiednio $6,74 \%$ dla $\mathrm{Zn}$ i $14,60 \%$ dla Zn-Al 85/15. Dla otwartego systemu rozpylania wpływ odległości natryskiwania jest zdecydowanie mniejszy, gdyż na podłożu osadza się przy odległości natryskiwania $600 \mathrm{~mm} \mathrm{30,82 \%} \mathrm{Zn} \mathrm{i} \mathrm{39,21 \%} \mathrm{Zn-Al} \mathrm{85/15.}$

Ze wzrostem odległości natryskiwania gęstość powłok uległa zmniejszeniu (tabl. IV).

\section{Wpływ kąta natryskiwania}

Wyniki pomiarów przedstawiono w tablicy V. Analizując te wyniki, szczególnie przy natryskiwaniu Zn z układem zamkniętym, należy bardzo dokładnie przestrzegać właściwego kąta natryskiwania, gdyż przy małych kątach straty rosną bardzo szybko. Interesujące jest to, że natryskiwanie stopu Zn-Al jest mniej zależne od kąta natryskiwania. 
Tablica IV. Przybliżona gęstość powłok w zależności od odległości natryskiwania

Table IV. Coating density depending on spraying distance

\begin{tabular}{|c|c|c|c|c|}
\hline \multirow{2}{*}{$\mathrm{L}, \mathrm{mm}$} & \multicolumn{2}{|c|}{$\mathrm{Zn, \textrm {g } / \mathrm { cm } ^ { 3 }}$} & \multicolumn{2}{c|}{$\mathrm{Zn}-\mathrm{Al} / 8515 \mathrm{~g} / \mathrm{cm}^{3}$} \\
\cline { 2 - 5 } & 0 & $\mathrm{z}$ & 0 & $\mathrm{z}$ \\
\hline 200 & 6,91 & 6,44 & 5,01 & 5,32 \\
\hline 600 & 4,65 & 5,23 & 4,37 & 4,94 \\
\hline
\end{tabular}

\section{Wpływ napięcia łuku}

Jak wykazały badania, wartość zastosowanego napięcia ma decydujący wpływ nie tylko na wielkość strat, lecz także na strukturę powłoki, w tym jej ziarnistość.

Pomiary wykonane przy napięciu łuku 19, 24 i $31 \mathrm{~V}$ wykazały jednoznacznie, że tylko przy napięciu $19 \mathrm{~V}$ pistolet pracuje równomiernie, a powłoka jest drobnoziarnista i zwarta. Mniejszy wpływ ma to na wartość współczynnika osadzania, która wynosi ok. 70\%.

\section{Wpływ ciśnienia powietrza rozpylającego}

Ciśnienie powietrza rozpylającego ma istotny wpływ na strukturę powłoki, szczególnie przy natryskiwaniu z układem otwartym. O ile przy układzie zamkniętym nawet przy ciśnieniu rozpylającym 0,2 MPa otrzymano drobnoziarniste powłoki, to przy układzie otwartym zastosowanie ciśnienia tej wielkości powoduje powstanie powłoki bardzo gruboziarnistej, porowatej i o nierównomiernej grubości. Wartość ciśnienia nie miała istotnego wpływu na wielkość strat.

\section{Wpływ rodzaju materiału powłokowego na koszt procesu}

Podczas natryskiwania obu materiałów powłokowych i przy przyjętych optymalnych parametrach: $I=200 \mathrm{~A}, \mathrm{U}=19 \mathrm{~V}, \mathrm{~L}=150 \mathrm{~mm}, \mathrm{p}=0,4 \mathrm{MPa}$, $\alpha=90^{\circ}$ wydajność pistoletu wynosiła dla otwartego układu rozpylania dla $\mathrm{Zn}-21,0 \mathrm{~kg} / \mathrm{h}$, dla $\mathrm{Zn}-\mathrm{Al}$ - 15,9 kg/h, a dla zamkniętego układu odpowiednio dla $\mathrm{Zn} \mathrm{-} \mathrm{22,4} \mathrm{i} \mathrm{dla} \mathrm{stopu} \mathrm{Zn-Al} \mathrm{-} \mathrm{17,2} \mathrm{kg/h.}$ Biorąc pod uwagę te wartości oraz dane podane w tablicy III, można określić wpływ odległości natryskiwania na wielkość powierzchni możliwej do pokrycia w ciągu $1 \mathrm{~h}$ (rys. 2) oraz koszt materiału powłokowego koniecznego do pokrycia $1 \mathrm{~m}^{2}$ powierzchni na grubość $100 \mathrm{~mm}$ (rys. 3).

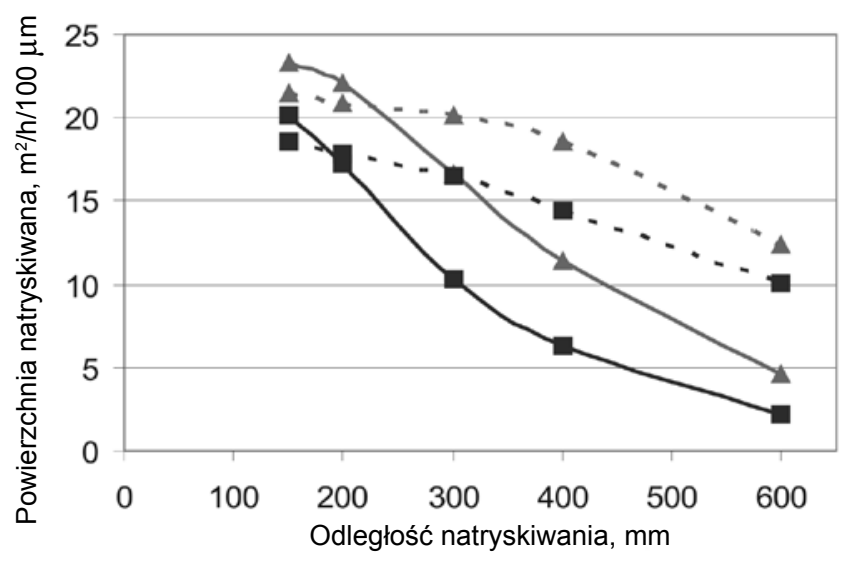

- -A- - Zn-Alo $\longrightarrow$ Zn-Al z - - - - Zno-ZZn z

Kys. z. vvpływ odıegłoscı natryskıwanıa na wielkosc powierzcnni możliwej do natryskania $\mathrm{w}$ ciągu $1 \mathrm{~h}$

Fig. 2. Effect of spraying distance on the size of surface to be sprayed within $1 \mathrm{~h}$

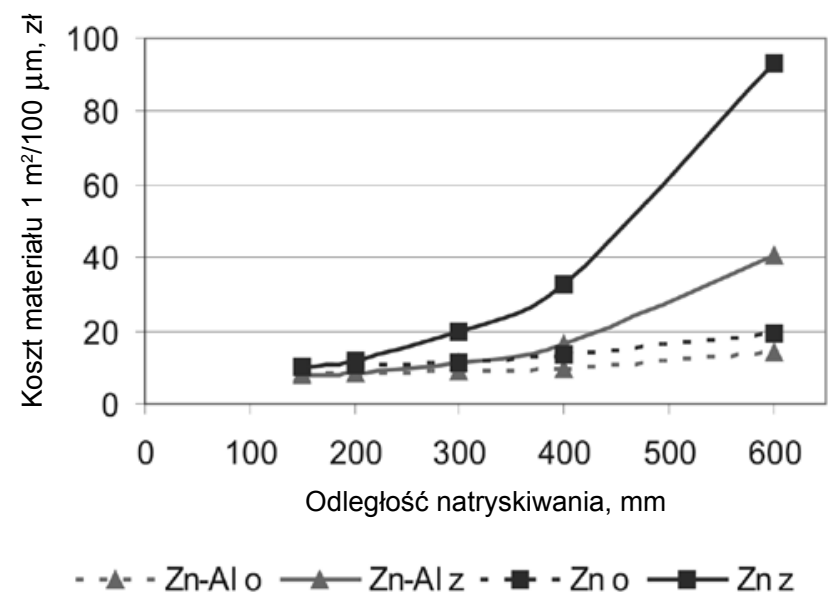

Rys. 3. Wpływ odległości natryskiwania na koszt materiału powłokowego koniecznego do pokrycia $1 \mathrm{~m}^{2}$ powierzchni na grubość $100 \mu \mathrm{m}$ Fig. 3. Effect of spraying distance on the costs of material volume to cover surface of $1 \mathrm{~m}^{2}$ surface with $100 \mu \mathrm{m}$ coating thickness

Tablica V. Wpływ kąta natryskiwania na wartość współczynnika osadzania dla powłok Zn i Zn-Al dla otwartego i zamkniętego układu rozpylania

Table $\mathbf{V}$. The influence of spraying angle on deposition efficiency for $\mathrm{Zn}$ and $\mathrm{Zn}-\mathrm{Al}$ coatings sprayed with open- and closed spraying system

\begin{tabular}{|c|c|c|c|c|}
\hline \multirow{2}{*}{ Kąt natryskiwania } & \multicolumn{2}{|c|}{ Zn, \% } & \multicolumn{2}{c|}{ Zn-Al 85/15, \% } \\
\cline { 2 - 5 } & 0 & $z$ & 0 & $z$ \\
\hline $90^{\circ}$ & 60,03 & 62,07 & 67,28 & 73,37 \\
\hline $60^{\circ}$ & 59,55 & 39,30 & 70,63 & 72,74 \\
\hline $45^{\circ}$ & 56,80 & 22,00 & 69,45 & 78,41 \\
\hline $30^{\circ}$ & 55,40 & 13,61 & 63,84 & 70,40 \\
\hline przy I = 200 A, L = 150 mm, $\mathrm{p}=0,4 \mathrm{MPa}, \mathrm{U}=19 \mathrm{~V}$ \\
\hline \multicolumn{5}{|c}{} \\
\hline
\end{tabular}




\section{Wnioski}

Do natryskiwania łukowego powłok $z \mathrm{Zn}$ lub stopu Zn-Al można stosować zarówno pistolety z zamkniętym, jak i z otwartym układem rozpylania.

Przy stosowaniu zamkniętego układu rozpylania bardzo ważne jest utrzymywanie stałej odległości natryskiwania nieprzekraczającej $200 \mathrm{~mm}$. Wzrost odległości natryskiwania powoduje gwałtowny wzrost strat do rzędu aż $93 \%$ dla Zn przy odległości $600 \mathrm{~mm}$ i $86 \%$ dla Zn-Al.

Otwarty układ rozpylania jest mniej wrażliwy na odległość natryskiwania. Straty wahają się dla Zn od $45 \%$ przy odległości $150 \mathrm{~mm}$ do $70 \%$ przy $600 \mathrm{~mm}$, a dla $\mathrm{Zn}-\mathrm{Al}$ od $33 \%$ dla $150 \mathrm{~mm}$ do $61 \%$ przy $600 \mathrm{~mm}$.

Zdecydowanie mniejsze straty materiału powłokowego występuja przy natryskiwaniu stopu Zn-Al niż czystego Zn. Przy optymalnym sposobie natryskiwania, tj. z odległości $150 \div 200 \mathrm{~mm}$ i przy zamkniętym układzie rozpylania straty te wynoszą dla $\mathrm{Zn}$ ok. $40 \%$, a dla Zn-Al ok. $28 \%$.
Z uzyskanych danych wynika, że koszt materiału powłokowego, koniecznego do natryskiwania $1 \mathrm{~m}^{2}$ powierzchni powłoką o grubości $100 \mu \mathrm{m}$, przy prawidłowych parametrach natryskiwania jest o ok. $20 \%$ mniejszy dla powłok ze stopu Zn-Al 85/15 niż powłok z Zn.

Szczególnie duży wpływ na strukturę powłoki ma wartość ciśnienia powietrza rozpylającego przy natryskiwaniu z układem otwartym. Przy układzie zamkniętym powłoki o prawidłowej ziarnistości uzyskuje się nawet przy obniżeniu ciśnienia do $0,2 \mathrm{MPa}$.

$\mathrm{Zn}$ i Zn-Al należy natryskiwać przy napięciu nie- przekraczającym $20 \mathrm{~V}$.

Ze zwiększeniem odległości natryskiwania maleje gęstość powłok, a więc wzrasta ich porowatość. Należy bezwzględnie zbadać, jaki ma to wpływ na odporność korozyjną całego systemu metalizacyjno-malarskiego. Badania w tym kierunku już podjęto.

\section{Literatura}

[1] Kwiatkowski L., Milewski W.: Powłoki metalowe w ochronie przed korozją konstrukcji stalowych. Informator Gospodarczy PIKS 2009.

[2] PN-EN ISO 14713-1:2010 Powłoki cynkowe - Wytyczne i zalecenia dotyczące ochrony przed korozją konstrukcji ze stopów żelaza - Część 1: Zasady ogólne dotyczące projektowania i odporności korozyjnej.

[3] Schweizerische Fachstelle Feuerverzinken (www.hdg-online.net).

[4] Thermal Spray Coatings-Past, Present \& Future Ted Call - District Sales Manager KTA - Tator, Inc. Pittsburgh, Pennsylvania, USA.

[5] DOT Wirginia 6-02.5 (13) OPT3FB6 Corrosion Protection, August 2010.

[6] Metallized coatings for corrosion control of naval ship structures and components. National Research Council (U.S.), National Materials Advisory Board. Washington, D.C.: National Academy Press, 1983.
[7] Mühlberg K.: Corrosion Protection for Windmills Onshore and Offshore. Hempel (Germany Ltd. Cologne, August 2004.

[8] Rahrig P.: Analyzing costs of galvanizing structural steel, Plant Engineering, October 2004.

[9] Roebuck A.H., Brevoort G.H.: Coating Works Costs: Computer Application and Inspection, CORROSION/86, National Association of Corrosion Engineers, Houston, Texas, 1986.

[10] Milewski W., Kobus J., Olbrycht A.: Koszt wykonania i eksploatacji powłok metalowych i metalowo-malarskich chroniących konstrukcje stalowe przed korozją. V Konferencja Naukowo-Techniczna PSK, Współczesne technologie przeciwkorozyjne, 2011.

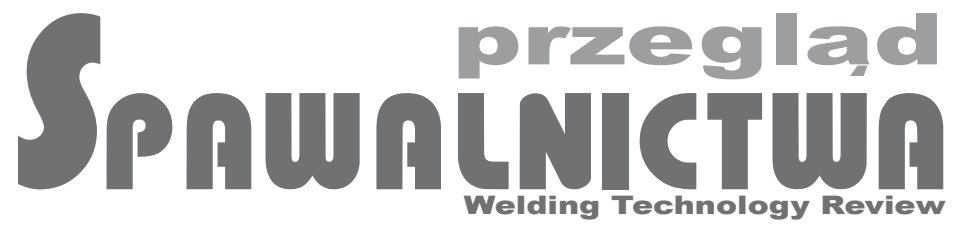

www.pspaw.ps.pl 